Article

\title{
Methodology for Assessment of Alternative Waste Treatment Strategies Using Entropy Weights
}

\author{
Zakariya Kaneesamkandi ${ }^{1}{ }^{\mathbb{D}}$, Ateekh Ur Rehman ${ }^{2, *} \mathbb{C}$, Yusuf Siraj Usmani ${ }^{2}$ and Usama Umer ${ }^{3}$ (i) \\ 1 Department of Mechanical Engineering, College of Engineering, King Saud University, \\ Riyadh 11421, Saudi Arabia; zkaneesamkandi@ksu.edu.sa \\ 2 Department of Industrial Engineering, College of Engineering, King Saud University, \\ Riyadh 11421, Saudi Arabia; yusmani@ksu.edu.sa \\ 3 Advanced Manufacturing Institute, King Saud University, Riyadh 11421, Saudi Arabia; uumer@ksu.edu.sa \\ * Correspondence: arehman@ksu.edu.sa; Tel.: +966-11-4697177
}

Received: 29 July 2020; Accepted: 13 August 2020; Published: 18 August 2020

check for updates

\begin{abstract}
Energy recovery from municipal solid waste is one of the means to attain sustainable development. Multiple factors involving several location specific situations, both measurable and intangible, makes decision making for technology selection very difficult. In this paper, a multi criterion evaluation system for municipal solid waste treatment strategies is established on the basis of specific, measurable, attainable, relevant and trackable situations, to prove the effectiveness of this method. From among various alternatives, three prominent strategies, namely, incineration, anaerobic digestion and composting are considered for the evaluation. Exhaustive data collection is done from conducting field studies, as well as from published data. Three types of communities are evaluated by this technique, namely, typical cities in developed countries, 'A' grade cities in India and ' $\mathrm{B}$ ' grade cities in India. The purpose of the study is to evaluate the effect of community specific situations on the right choice of waste disposal method using a technique for order of preference by similarity to ideal solution (TOPSIS) approach, where weights of criteria are determined by means of entropy weight method. The case study shows that the proposed evaluation results are reliable, which are more coincident with the reality, since the most relevant factors for selection have been used backed by exhaustive field data collection. Policy makers gain from the outcome of this study by guiding them through technology selection. So, the adopted approach should be promoted widely in the evaluation of waste treatment strategies, to realize sustainable development.
\end{abstract}

Keywords: solid waste; sustainable treatment; entropy weight; TOPSIS; waste management; strategies; decision analysis

\section{Introduction}

Sustainable development is achieved by including all available strategies for energy generation and development. The conventional energy economy is transforming into a non-conventional and energy efficient economy, mainly due to the environmental concern, namely, the greenhouse gas emissions. Waste disposal with energy recovery will continue to play a significant role in supporting the world's sustainable development initiatives, especially due to the rapid expansion of urban communities throughout the world. Considering global escalation in quantity of waste dumped, waste treatment strategies are an important issue that we need to focus on. Waste disposal strategies are required to evaluate comprehensively risk-free methodologies and to assess the proposed or existing strategies. Waste management makes use of theories and methods of waste management engineering, which are then put forward to corresponding environmental reforms according to cost and risks, to ensure environmental and public concerns. So, waste treatment strategies are an effective means to insure the 
safe operation of waste disposal methods. Since waste treatment strategies should consider several factors, choosing an appropriate method is often a challenge for decision makers. Therefore, it is important that the existing waste treatment strategies are complemented and further researched.

At present, the waste treatment evaluation strategies used are commonly divided into two kinds, namely, qualitative and quantitative evaluation methods. Wherein, qualitative evaluation methods have an expert evaluation method, safety check list method, fault hypothesis analysis method, etc. Quantitative evaluation methods have exponential method, probability method, fuzzy synthetic evaluation method, BP artificial neural network method, etc. These methods not only have their own characteristics and feasibility, but also have some drawbacks in the process adopted for disposal [1]. Multi-criteria decision making (MCDM) received much attention from researchers and practitioners in evaluating, assessing and ranking alternatives, across diverse industrial and non-industrial sectors. Behzadian et al. [2] reviewed the application of MCDM to solve diverse decision problems, and concluded that the technique for order preference by similarity to ideal solution (TOPSIS) is adopted across different decision making scenarios. For example, to evaluate urban sustainable development in China [3]; to evaluate the strategies for sustainable energy planning in Pakistan [4]; to select the right sustainable supplier [5]; to optimize renewable energy systems in Nigeria [6]; to evaluate the reuse of industrial waste [7]; and to select crop pattern as sustainable agriculture practice [8].

TOPSIS is a widely accepted MCDM approach, which take into consideration both the positive (i.e., best) and the negative (i.e., worst) solutions, and easy to compute and implement procedure. Its basic principle has to do with the fact that the chosen alternative should have the shortest distance from the positive ideal solution and the farthest from the negative ideal solution, compared to the others. The weakness of the TOPSIS is that being not able to deal with decision-makers' ambiguities and uncertainties in determining weights of criterion and sub criterion, this weakness is overcome by estimation of criterion weights using an entropy approach.

In this paper, a comprehensive evaluation model of waste treatment strategies is established by use of the entropy weight and TOPSIS, which is then applied to evaluate three waste treatment strategies at three different levels, to improve the level of green management and ensure the safety of environment and people.

The level of development in a community determines the technical feasibility and techno economics of the treatment strategy at different stages of its implementation. Economic factors were found to influence waste generation rate and composition, as indicated in the study of households at different levels in Srilanka [9]. The level of urbanization strongly determines waste production levels in terms of quantity as well as quality. Infrastructure availability for collection, handling/transportation of the waste are also factors dependent on the economic level of the community. Table 1 makes a comparison of waste generation data for three different types of communities, namely, a European city (hence forth termed as Type 1 Cities), an 'A' grade Indian city (hence forth termed as Type 2 Cities) and a ' $\mathrm{B}$ ' grade Indian city (hence forth termed as Type 3 Cities).

Type 1 cities have more experience with waste prevention than other regions, and recycling and materials recovery are well supported in Northern Europe. While the share of waste from households' ranges for most countries between $60 \%$ and $90 \%$ under the responsibility of the municipality, the percentage of commercial waste in municipal waste ranges for most countries between $10 \%$ and $35 \%$. Type 1 cities are classified into five levels from Class 1 to Class 5 on an economic basis. High income countries prefer incineration while low income countries go for landfills as an ideal option [21]. Recently, the favorable option leans in favor of incineration, due to the energy recovery possibility for which the carbon and hydrogen content in waste content must meet required standards.

Type 2 cities have a very high per capita waste generation rate. The annual generation varies between 0.8 million tons to 2.4 million tons depending on the area and population. Adequate infrastructure to meet the requirements of the waste disposal activity are provided in these cities. Moreover, consistency in generation is ensured qualitatively and quantitatively. The public 
perception and market for purchasing the end product of waste disposal, like energy, gas or compost is also promising in these cities [22]. Average percentage of carbon content in the waste is about $64 \%$.

Table 1. Waste Generation Statistics under Type 1 Cities, Type 2 Cities and Type 3 Cities.

\begin{tabular}{cccccc}
\hline Category & City & Area $\left.\mathbf{( k m}^{\mathbf{2}}\right)$ & Population & $\begin{array}{c}\text { Total Waste Generated in } \\
\text { Tons Per Year }\end{array}$ & $\begin{array}{c}\text { Organic } \\
\text { Content }\end{array}$ \\
\hline \multirow{5}{*}{ Type 1 cities } & Paris & 105.4 & $2,274,880$ & $1,113,438$ & $52 \%[10]$ \\
& Berlin & 892 & $3,398,526$ & $1,341,515$ & $52 \%[11]$ \\
& London & 1572.15 & $8,173,941$ & $3,560,990$ & $54 \%[10]$ \\
& Amsterdam & 219 & 799,345 & 324,302 & $45 \%[12]$ \\
\hline \multirow{5}{*}{ Type 2 cities } & New Delhi & 1484 & $18,600,000$ & $2,555,000$ & $73.7 \%[13]$ \\
& Mumbai & 437.7 & $12,000,000$ & $2,190,000$ & $65 \%[14]$ \\
& Calcutta & 200.71 & $14,112,536$ & $1,765,505$ & $62 \%[15]$ \\
& Chennai & 1189 & $8,653,521$ & 985,500 & $55 \%[16]$ \\
\hline \multirow{5}{*}{ Type 3 cities } & Nagpur & 227 & $2,400,000$ & 408,435 & $63 \%[17]$ \\
& Nasik & 259 & $1,076,967$ & 118,625 & $58 \%[18]$ \\
& Tiruchirappalli & 164.7 & 847,387 & 182,500 & $64 \%[19]$ \\
& Raipur & 226 & $1,010,000$ & 148,920 & $60 \%[20]$ \\
\hline
\end{tabular}

Contrary to the Type 2 cities, Type 3 cities give a different set of scenarios in terms of waste generation quantity and infrastructure availability. Generation in these cities are in between 0.07 million tons and 0.15 million tons per year [23]. Average percentage of carbon content in the waste is about $61 \%$. The aim of this paper is to prove the effectiveness of this approach in accurately considering the weight of the different factors obtained from field data.

In the current study, a multi criteria decision making approach (MCDM) is proposed to evaluate the effect of community specific situations on the right choice of waste disposal method, where weights of multiple criteria are determined by means of entropy weight method. The proposed approach results are reliable, which are more coincident with reality. The approach will guide policy makers to do technology selection for evaluation of waste treatment strategies.

\section{Technologies for Waste to Energy Conversion}

Municipal solid waste (MSW) contains a considerable amount of carbonaceous matter which has energy value. The technologies existing for producing energy from conventional fuels have been tried on municipal waste as well. This includes incineration, thermal gasification, bio-gasification and pyrolysis. Apart from this, composting and landfills are methods used specifically for waste conversion. The type of technology used for conversion depends on the local characteristics of the waste apart from economic and political issues. Nevertheless, disposal of waste is the primary need which has become the main activity of the municipal bodies managing the ever-expanding urban communities. In this paper, three methods of disposal, namely, incineration, anaerobic digestion and composting, are considered for the analysis.

\subsection{Incineration}

The waste is directly burned in a furnace by supplying air for combustion (Figure 1). This is usually preceded by a preparation process in which the undesirable matters are removed. The volume of the waste is reduced by $95 \%$ in this method [24]. The heat produced during the combustion can be converted to electricity by using a boiler or can be directly as heat for residential or industrial process heating needs. Issues related with exhaust gas emissions depend on the chemical composition of the waste and methods to clean these gases are installed depending on specific cases. 


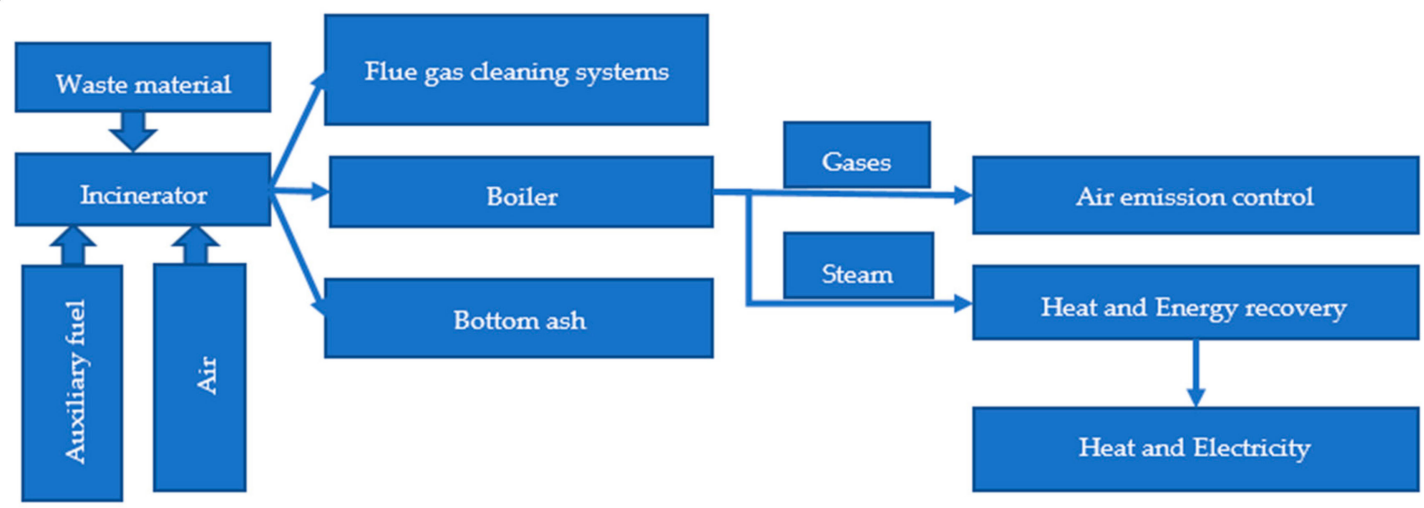

Figure 1. Process of incineration of municipal solid waste management.

Economic feasibility of a waste incineration process is under question due to the high investment required, high risk involved, environmental consequences and availability of other competing waste utilization methods like re-cycling or composting [25]. Incineration is a very expensive option in terms of initial investment and required established infrastructural facility, like well-organized collection system, adequate transportation network, apart from social factors. The Type 1 cities as well as Type 2 cities are well ahead compared to Type 3 cities, where development of sufficient infrastructure is still pending.

One of the pre-conditions for successful operation of incineration facility is that more than 100,000 tons/year of waste must be generated. Furthermore, the lower calorific value of the waste should not be less than $7 \mathrm{MJ} / \mathrm{kg}$. Developing economies have high moisture and organics in the waste, that make this condition a challenge [25].

\subsection{Anaerobic Digestion}

Waste occurring at high moisture content and with right carbon nitrogen ratio is suited for this technology (Figure 2). The product is gas with combustible components that include methane, carbon monoxide and hydrogen. This method is suitable for low capacity waste generation. Proper management of the system and mixing with other fuels like agricultural waste or animal wastes can improve the reliability of the process, as well as the quantity of the product gas, which can be substituted for petrol as a transport fuel. The quantity of gas produced depends on a several operating factors [16]. The end products available from this technology are electricity which is produced by running gas turbine bases power plant or boiler-based power plant, as well as the digestate and liquor sale, which have high nutritional value for agricultural purposes. Compared to incineration, anaerobic digestion requires more control on the quality of the waste collected. Segregation of the waste is done at the source level or at the dumping site.

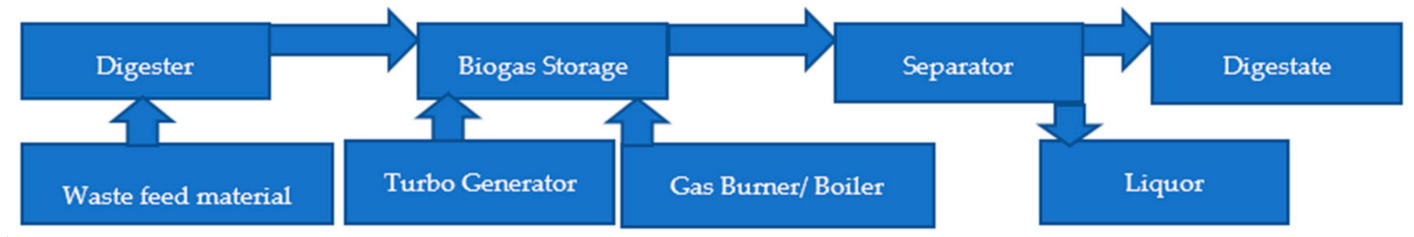

Figure 2. Process of anaerobic digestion of municipal solid waste management.

\subsection{Composting}

This is becoming an increasingly popular method of waste disposal (Figure 3). This method can also help to separate recyclable constituents. However, the presence of heavy metals and biological contaminants is a hazard. This method is the best option for land remediation and restoring the nutritional content of the soil. Composting MSW is an economically sound method to address the 
MSW disposal problems $[16,26]$. Windrow composting is the most common method of production of compost. IN this technology, the waste is humidified and periodically turned to expose to air for the composting reactions to take place. Composting is the most flexible and convenient option that can be implemented in any level of community. Prevention of leachates and control of emissions are required at the facility. The end product must have adequate buyers in the surroundings.

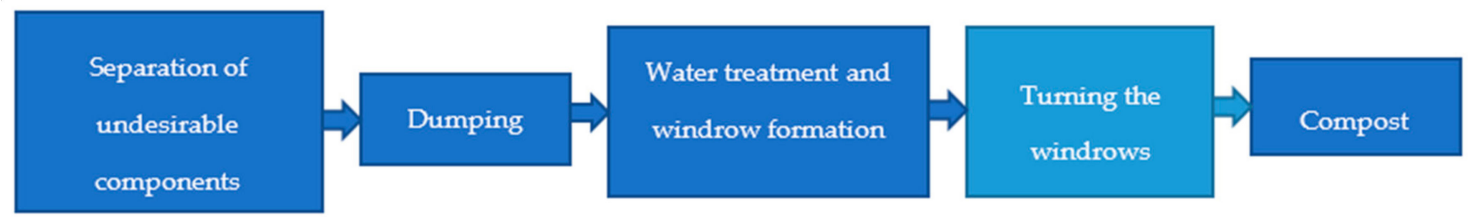

Figure 3. Process of composting of municipal solid waste management.

\section{Evaluation Criteria and Entropy Weights}

\subsection{Principles}

Waste treatment strategies are complex due to the involvement of different parameters. Municipal solid waste (MSW) has an energy value which can fetch considerable returns in terms revenue from sale of energy. The technologies, such as incineration, thermal gasification, bio-gasification and pyrolysis, are methods used specifically for waste conversion. Disposal of waste is the primary need which has become the main activity of the municipal bodies managing the ever-expanding urban communities. In this paper, three methods of waste conversion, namely, incineration, anaerobic digestion and composting, are considered for the evaluation.

\subsection{Evaluation Index System}

On the basis of 'Safety in waste management of Republic of India', 'Safety in Production Law in waste management', 'Regulations in waste management' and other relevant laws and regulations, as well as spot studies and relevant references combining with experts' opinion and questionnaire, evaluation criteria system of waste treatment strategies is established and shown in the Table 2.

Table 2. Evaluation criteria for waste treatment.

\begin{tabular}{|c|c|c|c|c|}
\hline \multirow{2}{*}{ Criterion Category } & \multirow{2}{*}{$\begin{array}{l}\text { 'j' Evaluation } \\
\text { Criterion }\end{array}$} & \multicolumn{3}{|c|}{ Evaluation Criterion ' $j$ ' } \\
\hline & & Name & Unit & Objective \\
\hline \multirow{15}{*}{$\begin{array}{l}\text { Environmental } \\
\text { Concerns }\end{array}$} & 1 & $\mathrm{CO}_{2}$ & Kilo gram per ton & minimization \\
\hline & 2 & $\mathrm{CO}$ & Gram per ton & minimization \\
\hline & 3 & $\mathrm{SO}_{2}$ & Gram per ton & minimization \\
\hline & 4 & NOX & Gram per ton & minimization \\
\hline & 5 & $\mathrm{~N}_{2} \mathrm{O}$ & Gram per ton & minimization \\
\hline & 6 & HCL & Gram per ton & minimization \\
\hline & 7 & $\mathrm{NH}_{3}$ & Gram per ton & minimization \\
\hline & 8 & $\mathrm{HF}$ & Gram per ton & minimization \\
\hline & 9 & Particulate matter & Gram per ton & minimization \\
\hline & 10 & Dioxins/Furans & Nano gram per ton & minimization \\
\hline & 11 & $\begin{array}{l}\text { Poly-aromatic } \\
\text { hydrocarbons }\end{array}$ & Milli gram per ton & minimization \\
\hline & 12 & $\begin{array}{l}\text { Cadmium and } \\
\text { thallium }\end{array}$ & Milli gram per ton & minimization \\
\hline & 13 & Mercury & Milli gram per ton & minimization \\
\hline & 14 & Other heavy metals & Milli gram per ton & minimization \\
\hline & 15 & $\mathrm{CH}_{4}$ & Gram per ton & minimization \\
\hline
\end{tabular}


Table 2. Cont.

\begin{tabular}{|c|c|c|c|c|}
\hline \multirow{2}{*}{ Criterion Category } & \multirow{2}{*}{$\begin{array}{l}\text { 'j' Evaluation } \\
\text { Criterion }\end{array}$} & \multicolumn{3}{|c|}{ Evaluation Criterion ' $j$ ' } \\
\hline & & Name & Unit & Objective \\
\hline \multirow[t]{2}{*}{ Cost Concerns } & 16 & $\begin{array}{l}\text { Initial investment } \\
\text { cost }\end{array}$ & $\begin{array}{l}\text { Million USD per } \\
\text { ton per year }\end{array}$ & minimization \\
\hline & 17 & Operating Cost & $\begin{array}{l}\text { Million USD per } \\
\text { ton per year }\end{array}$ & minimization \\
\hline \multirow{2}{*}{ End Product Cost } & 18 & \multirow{2}{*}{$\begin{array}{l}\text { Electricity/Gas/Compost } \\
\text { Market availability } \\
\text { for the end product }\end{array}$} & USD per ton & minimization \\
\hline & 19 & & Descriptive scale & minimization \\
\hline \multirow{2}{*}{$\begin{array}{l}\text { Ability to Tolerate } \\
\text { Raw Material } \\
\text { Supply Variation }\end{array}$} & 20 & $\begin{array}{l}\text { Meeting the } \\
\text { minimum supply } \\
\text { rate of waste }\end{array}$ & Descriptive scale & maximization \\
\hline & 21 & $\begin{array}{l}\text { Meeting the fuel } \\
\text { quality } \\
\text { requirement }\end{array}$ & Descriptive scale & maximization \\
\hline Public Perception & 22 & Public Perception & Descriptive scale & maximization \\
\hline
\end{tabular}

\subsection{Estimation of Criterion Weights: Entropy Approach}

When determining weights of criterion and sub criterion, subjective fixed weight methods such as the Delphi method, expert survey method, the analytic hierarchy process method (AHP), etc., are usually used. They could lead to deviations of criterion and sub criterion' weights, due to subjective factors. Meanwhile, objective fixed weight methods are based on the inherent information of indexes to determine weights of criterion and sub criterion, which could eliminate man-made disturbances and make results in more accord with facts. In information theory, the entropy by Shannon can be used to determine the disorder degree and its utility in system information. The smaller the entropy value is, the smaller the disorder degree of the system is. Entropy weight method is based on amount of information to determine the index's weight, which is one of the objective fixed weight methods. In this paper, the entropy weight method is adopted to determine the weight of the criterion and sub criterion, which is calculated as follows.

\subsection{Standardization of Criteria and Sub Criteria}

Supposing there are ' $\mathrm{m}$ ' waste treatment strategies and ' $\mathrm{n}$ ' evaluation criteria in the system, $\mathrm{X}_{\mathrm{ij}}$ is the jth criterion's value in the ith waste treatment strategy. In order to eliminate the influence of criteria dimension on incommensurability, it is necessary to standardize criteria using the equations of relative optimum membership degree. To the benefit (maximize) criterion, the attribute value of the jth criterion in the ith waste treatment strategy can be standardized by using Equation (1).

$$
S_{i j}=\left[\frac{X_{i j}-\min _{j} X_{i j}}{\max _{j} X_{i j}-\min _{j} X_{i j}}\right]
$$

In above Equation (1), $S_{\mathrm{ij}}$ is the standardized criterion value of the jth maximization criterion of the ith waste treatment strategy; $X_{i j}$ is the actual measured value of jth criterion for the ith waste treatment strategy as presented in the following Table 3 , where $i=1$ to $m$ and $j=1$ to $n$. 
Table 3. Decision matrix with criterion weights.

\begin{tabular}{ccccc}
\hline $\begin{array}{c}\text { Evaluation Criterion } \mathbf{( j )} \rightarrow \\
\text { Alternative Waste Treatment Strategies (WTS) (i) } \downarrow\end{array}$ & $\mathbf{1}$ & $\mathbf{2}$ & $\cdot$ & $\mathbf{n}$ \\
\hline 1 & $\mathrm{X}_{11}$ & $\mathrm{X}_{12}$ & $\cdot$ & $\mathrm{X}_{1 \mathrm{n}}$ \\
2 & $\mathrm{X}_{21}$ & $\mathrm{X}_{22}$ & $\cdot$ & $\mathrm{X}_{2 \mathrm{n}}$ \\
$\mathrm{a}$ & $\mathrm{X}_{\mathrm{a} 1}$ & $\mathrm{X}_{\mathrm{a} 2}$ & $\cdot$ & $\mathrm{X}_{\mathrm{an}}$ \\
$\cdot$ & $\cdot$ & $\cdot$ & $\cdot$ & $\cdot$ \\
$\mathrm{b}$ & $\mathrm{X}_{\mathrm{b} 1}$ & $\mathrm{X}_{\mathrm{b} 2}$ & $\cdot$ & $\mathrm{X}_{\mathrm{bn}}$ \\
$\cdot$ & $\cdot$ & $\cdot$ & $\cdot$ & $\cdot$ \\
$\mathrm{m}$ & $\mathrm{X}_{\mathrm{m} 1}$ & $\mathrm{X}_{\mathrm{m} 2}$ & $\cdot$ & $\mathrm{X}_{\mathrm{mn}}$ \\
Criterion Weight $\rightarrow$ & $\mathrm{W}_{1}$ & $\mathrm{~W}_{2}$ & $\cdot$ & $\mathrm{W}_{\mathrm{n}}$ \\
\hline
\end{tabular}

Note: $X_{\mathrm{mn}}$ is criterion measurement for mth treatment strategy and $n$th evaluation criterion; and $W_{\mathrm{n}}$ is weight assigned to criterion $\mathrm{j}$.

For a minimization criterion, the attributed value of the jth criterion in the ith waste treatment strategy can be standardized by using Equation (2).

$$
S_{i j}=\left[\frac{\max _{j} X_{i j}-X_{i j}}{\max _{j} X_{i j}-\min _{j} X_{i j}}\right]
$$

In above Equation (2), $S_{\mathrm{ij}}$ is the standardized criterion value of the jth minimization criterion for the ith waste treatment strategy; $X_{i j}$ is the actual measured value of $j$ th criterion for the ith waste treatment strategy, where $i=1$ to $m$ and $j=1$ to $n$.

After standardization of all the evaluation criteria, the decision matrix is expressed as Equation (3):

$$
\mathrm{S}_{\mathrm{ij}}^{\prime}=\left[\begin{array}{cccc}
\mathrm{S}_{11} & \mathrm{~S}_{12} & \ldots & \mathrm{S}_{1 \mathrm{n}} \\
: & : & : & : \\
: & : & : & : \\
\mathrm{S}_{\mathrm{m} 1} & \mathrm{~S}_{\mathrm{m} 2} & \ldots & \mathrm{S}_{\mathrm{mn}}
\end{array}\right]
$$

In the above matrix Equation (3), $\mathrm{S}_{\mathrm{mn}}$ is the standardized criterion value of the $\mathrm{nth}$ criterion for the $\mathrm{mth}$ waste treatment strategy; and $\mathrm{S}_{\mathrm{ij}}{ }^{\prime}$ is the matrix representation of standardized values of all evaluation criteria.

According to the definition of entropy, $E_{j}$ is the entropy (for the objective weight) of the jth criterion, and is determined by Equation (4).

$$
E_{j}=-\frac{\sum_{i=1}^{m}\left[S_{i j} * \ln \left(S_{i j}\right)\right]}{\ln (m)}
$$

In above Equation (4), $\mathrm{S}_{\mathrm{ij}}$ is the standardized criterion value of the $\mathrm{jth}$ criterion for the ith waste treatment strategy; and $E_{j}$ is the entropy value of $j$ th evaluation criteria.

Subsequently, based on $E_{j}$ of the jth criterion, $W_{j}$, the criterion entropy weights, is determined by using Equation (5).

$$
W_{j}=\frac{1-E_{j}}{\left[1-\sum_{j=1}^{n} E_{j}\right]}
$$

In above Equation (5), $E_{j}$ is the entropy value of $j$ th evaluation criteria, $n$ is the total number of criterions and $W_{j}$ is $j$ th criterion entropy weightage.

The entropy weight represents useful information of the evaluation criterion. Therefore, the higher the entropy weight of the evaluation criterion, the more important the criterion. The reverse is also true. 


\section{MCDM Model: Based on TOPSIS and Entropy Weights}

TOPSIS is a MCDM approach that can be applied when a set of alternatives must be ranked according to a set of criteria reflecting the decision maker's preferences [27]. This approach is straightforward, and the concept permits the pursuit of best alternatives for each criterion depicted in a simple mathematical form, and the importance weights are incorporated into the comparison procedures. In this study, the TOPSIS method, which is very simple and easy to implement, was used to select the preference order of the alternative waste treatment strategies.

TOPSIS selects the alternative that is the closest to the ideal solution and farthest from the negative ideal alternative. For a given set of $m$ alternatives (options) and $n$ attributes/criteria and the score of each option with respect to each criterion, let $X_{i j}$ be a score of option $i$ with respect to criterion $j$. We have a $\mathrm{m} \times \mathrm{n}$ matrix $\mathrm{X}=\left(\mathrm{X}_{\mathrm{ij}}\right)$. Let $\mathrm{J}$ be the set of benefit attributes or criteria (more is better) and $\mathrm{J}^{\prime}$ be the set of negative attributes or criteria (less is better). The steps in TOPSIS approach are as [28]:

\subsection{Structure of the Decision Matrix}

Supposing the evaluation set of multi-attribute decision making problem has the jth criterion's value in the ith waste treatment strategy is $X_{i j}$, then the decision matrix is $X=\left[X_{i j}\right] m \times n$; refer to Table 1 .

\subsection{Normalization of the Decision Matrix}

In order to eliminate the influence of criteria dimension and its variation range on evaluation results, it is necessary to normalize the original matrix to ensure that all the attributes are equivalent and the same format, then the normalized decision matrix is $\mathrm{R}_{\mathrm{ij}}$ is obtained using Equation (6).

$$
\mathrm{R}_{\mathrm{ij}}=\frac{\mathrm{X}_{\mathrm{ij}}}{\sqrt{\sum \mathrm{X}_{\mathrm{ij}}^{2}}}
$$

In the above Equation (6), $R_{\mathrm{ij}}$ is the normalized criterion value of the jth criterion of the ith waste treatment strategy; $X_{i j}$ is the actual measured value of $\mathrm{jth}$ criterion for the ith waste treatment strategy, where $i=1$ to $m$ and $j=1$ to $n$.

\subsection{Determine Best and Worst Solutions for a Given Criterion}

Multiply each element of the above normalized decision matrix by respective entropy weight $\left(\mathrm{W}_{\mathrm{j}}\right)$; this results into weighed normalized decision matrix (refer to Equation (7)).

$$
\mathrm{V}_{\mathrm{ij}}=\mathrm{W}_{\mathrm{j}} * \mathrm{R}_{\mathrm{ij}}
$$

In the above Equation (7), $R_{i j}$ is the normalized criterion value of the $j$ th criterion of the ith waste treatment strategy; $W_{j}$ is the estimated entropy weight for $j$ th criterion, where $i=1$ to $m$ and $j=1$ to $n$; and $V_{i j}$ is the weighted normalized criterion value of the jth criterion of the ith waste treatment strategy.

The outcome of above Equation (7) results in a set of best and worst solutions, and are obtained using Equations (8) and (9), respectively.

$$
\mathrm{V}^{+}=\text {Best soultion }=\left\{\mathrm{V}_{1}^{+}, \ldots \mathrm{V}_{\mathrm{j}}^{+}, \ldots \mathrm{V}_{\mathrm{n}}^{+}\right\}
$$

In above Equation (8),

$$
\begin{gathered}
\mathrm{V}_{\mathrm{j}}^{+}=\left\{\operatorname{maxi}\left(\mathrm{V}_{\mathrm{ij}}\right) \text { if } \mathrm{j} \in \text { maximization criteria; } \operatorname{mini}\left(\mathrm{V}_{\mathrm{ij}}\right) \text { if } \mathrm{j} \in \operatorname{minimization} \text { criteria }\right\} \\
\mathrm{V}^{-}=\text {Worst soultion }=\left\{\mathrm{V}_{1}^{-}, \ldots \mathrm{V}_{\mathrm{j}}^{-}, \ldots \mathrm{V}_{\mathrm{n}}^{-}\right\}
\end{gathered}
$$

In above Equation (9), 


$$
\mathrm{V}_{\mathrm{j}}^{-}=\left\{\operatorname{mini}\left(\mathrm{V}_{\mathrm{ij}}\right) \text { if } \mathrm{j} \in \text { minimization criteria; } \operatorname{maxi}\left(\mathrm{V}_{\mathrm{ij}}\right) \text { if } \mathrm{j} \in \text { maximization criteria }\right\}
$$

\subsection{Determine the Distance Measures for Each Alternative}

For a given alternative, its distance from the best ideal alternative is obtained using Equation (10);

$$
\mathrm{D}_{\mathrm{i}}^{+}=\sqrt{\sum_{\mathrm{j}}\left(\mathrm{V}_{\mathrm{j}}^{+}-\mathrm{V}_{\mathrm{ij}}\right)}
$$

In the above Equation (10), $\mathrm{i}=1$ to $\mathrm{m}$ and $\mathrm{j}=1$ to $n ; \mathrm{V}_{\mathrm{ij}}$ is the weighted normalized criterion value of the jth criterion of the ith waste treatment strategy; $\mathrm{V}_{j}{ }^{+}$is the best value among $\mathrm{j}$ criterion; and $\mathrm{D}_{\mathrm{i}}{ }^{+}$is the positive separation (distance) value of the ith waste treatment strategy.

For a given alternative, its distance from the worst ideal alternative is obtained using Equation (11).

$$
\mathrm{D}_{\mathrm{i}}^{-}=\sqrt{\sum_{\mathrm{j}}\left(\mathrm{V}_{\mathrm{j}}^{-}-\mathrm{V}_{\mathrm{ij}}\right)}
$$

In the above Equation (11), $i=1$ to $m$ and $j=1$ to $n ; V_{i j}$ is the weighted normalized criterion value of the jth criterion of the ith waste treatment strategy; $V_{j}{ }^{-}$is the worst value among ' $j$ ' criterion; and $\mathrm{D}_{\mathrm{i}}{ }^{-}$is the negative separation (distance) value of the ith waste treatment strategy.

\subsection{Determine Closeness to Ideal Solution for Each Alternative and Rank the Alternative}

For a given alternative, its closeness to ideal alternative is obtained using Equation (12).

$$
C_{i}=\frac{D_{i}^{-}}{D_{i}^{+}-D_{i}^{-}}
$$

In above Equation (12), $C_{i}$ value ranges in between one and zero. The alternative $i$ with maximum positive value of $C_{i}$ is ranked as number one.

\section{Case Study}

Three waste management strategies, in accordance with relevant waste disposal regulations, are examined and tested for three different scenarios; namely Type 1 cities, Type 2 cities and Type 3 cities. Surveyed data of evaluation criteria corresponding to waste management strategies are presented in the Tables 4-6. The objective is to evaluate three waste treatment strategies in order to improve the level of green management index and ensure the safety of environment and people. Data pertaining to each evaluation criteria connected with each of the different treatment strategies are unique. The details of each criterion are briefed in the following subsections.

\subsection{Environmental Concerns}

The environmental effect of municipal waste incineration was studied in detail by Jeswani and Azapagic [29], and the emission contents were individually quantified. Carbon dioxide is the chief greenhouse gas (GHG) produced from the biogenic and fossil carbon fraction in the wastes. Although the normal assumption is $1 \mathrm{t}$ of $\mathrm{CO}_{2}$ per ton of waste, values greatly vary for different regions depending on the waste composition. The $\mathrm{CO}_{2}$ produced is calculated for the actual carbon content data. Carbon monoxide emissions result when carbon in the waste is not oxidized to carbon dioxide $\left(\mathrm{CO}_{2}\right)$. The procedure to calculate the quantity of $\mathrm{CO}_{2}$ produced during the incineration of waste depends on the carbon in the fuel, which is basically of both biogenic origin and fossil origin. Assuming that $33 \%$ of the carbon is of fossil origin and $67 \%$ is of biogenic origin, the $\mathrm{CO}_{2}$ production per ton of waste is calculated to be $0.415 \mathrm{t}$ per ton of waste [30]. Incineration technology with the 
different temperature ranges and gas cleaning systems as well as the waste composition determine most of the other emissions, like sulphur dioxide, nitrous oxides, ammonia, dioxins and furans.

Table 4. The surveyed data of for Type cities 1 for three types of treatment strategies.

\begin{tabular}{cccc}
\hline \multirow{2}{*}{ Evaluation Criterion *.j } & \multicolumn{3}{c}{ Alternative Waste Treatment Strategy (i) } \\
\cline { 2 - 4 } & Incineration (i = 1) & Anaerobic Digestion (i = 2) & Composting (i = 3) \\
\hline 1 & 415 & 89.1 & 182 \\
2 & 48.7 & 0 & 0 \\
3 & 94.9 & 0.009 & 394.8 \\
4 & 0.9 & 0.57 & 10 \\
5 & 1.7 & 37.57 & 178 \\
6 & 32.3 & $6.1 \times 10^{-5}$ & 0 \\
7 & 17.9 & 0.16 & 300 \\
8 & 3 & $2.1 \times 10^{-5}$ & 0 \\
9 & 17.9 & 0 & 0 \\
10 & 92.3 & 0 & 100.2 \\
11 & 1.7 & 0 & 0 \\
12 & 5.1 & $3.02 \times 10^{-7}$ & 0 \\
13 & 7.7 & $1.81 \times 10^{-3}$ & 0 \\
14 & 102.9 & $1.5 \times 10^{-6}$ & 600 \\
15 & 0 & 5 & 0.0049 \\
16 & 640 & 561 & 0.011 \\
17 & 19.2 & 0.00369 & 50 \\
18 & 108 & 101 & Poor \\
19 & Good & Average & Average \\
20 & Good & Good & Average \\
21 & Good & Good & Average \\
22 & Good & Good &
\end{tabular}

Note: * refer Table 2 for criterion names, units, and their objective.

Table 5. The surveyed data of for Type cities 2 for three types of treatment strategies.

\begin{tabular}{|c|c|c|c|}
\hline \multirow{2}{*}{$\mathbf{j} \downarrow$ Evaluation Criterion * } & \multicolumn{3}{|c|}{ Alternative Waste Treatment Strategy (i) } \\
\hline & Incineration $(i=1)$ & Anaerobic Digestion $(i=2)$ & Composting $(\mathrm{i}=3)$ \\
\hline 1 & 578.56 & 124.08 & 253.72 \\
\hline 2 & 62.336 & 0 & 0 \\
\hline 3 & 121.472 & 0.01152 & 505.344 \\
\hline 4 & 1.152 & 0.7296 & 12.8 \\
\hline 5 & 2.176 & 16.64 & 70.4 \\
\hline 6 & 41.344 & $7.81 \times 10^{-5}$ & 0 \\
\hline 7 & 22.912 & 200.96 & 30.72 \\
\hline 8 & 3.84 & $2.69 \times 10^{-5}$ & 0 \\
\hline 9 & 22.912 & 0 & 0 \\
\hline 10 & 118.144 & 0 & 0 \\
\hline 11 & 2.176 & 0 & 128.256 \\
\hline 12 & 6.528 & $3.87 \times 10^{-7}$ & 0 \\
\hline 13 & 9.856 & 0.002317 & 0 \\
\hline 14 & 131.712 & $1.92 \times 10^{-6}$ & 0 \\
\hline 15 & 0 & 1216 & 836.47 \\
\hline 16 & 428 & 375 & 0.0032 \\
\hline 17 & 3.88 & 0.000747 & 0.0022 \\
\hline 18 & 108 & 101 & 50 \\
\hline 19 & Good & Good & Poor \\
\hline 20 & Good & Good & Average \\
\hline 21 & Good & Good & Average \\
\hline 22 & Good & Good & Average \\
\hline
\end{tabular}

Note: * refer Table 2 for criterion names, units, and their objective. 
Table 6. The surveyed data of for Type cities 3 for three types of treatment strategies.

\begin{tabular}{cccc}
\hline \multirow{2}{*}{$\mathbf{j} \downarrow$ Evaluation Criterion * Alternative Waste Treatment Strategy (i) } \\
\cline { 2 - 4 } & Incineration (i = 1) & Anaerobic Digestion (i = 2) & Composting (i = 3) \\
\hline 1 & 551.44 & 118.38 & 241.8 \\
2 & 64.7 & 0 & 0 \\
3 & 0 & 0 & 0 \\
4 & 1.098 & 0.6954 & 12.2 \\
5 & 2.074 & 15.86 & 67.1 \\
6 & 39.406 & $7.44 \times 10^{-5}$ & 0 \\
7 & 21.838 & 191.54 & 29.28 \\
8 & 3.66 & $2.56 \times 10^{-5}$ & 0 \\
9 & 21.838 & 0 & 0 \\
10 & 112.606 & 0 & 0 \\
11 & 2.074 & 0 & 122.244 \\
12 & 6.222 & $3.68 \times 10^{-7}$ & 0 \\
13 & 9.394 & 0.002208 & 0 \\
14 & 125.538 & $1.83 \times 10^{-6}$ & 0 \\
15 & 0 & 1159 & 797.26 \\
16 & 428 & 375 & 0.0032 \\
17 & 3.18 & 0.000647 & 0.0018 \\
18 & 108 & 101 & $50 \$$ per ton \\
19 & Average & Good & Good \\
20 & Poor & Good & Good \\
21 & Poor & Good & Good \\
22 & Good & Average & Good \\
\hline
\end{tabular}

Note: * refer Table 2 for criterion names, units, and their objective.

Anaerobic digestion of MSW is an anaerobic digestion process which generates about 100 to $200 \mathrm{~m}^{3}$ of gas per ton of waste, depending on the quality of the waste and other influencing factors [31]. Das et al. [32] elaborate the formula used to estimate the gas production rate based upon the stoichiometry of the degradation reaction of the waste. This procedure was used to determine the gas production rate from the MSW data collected from the site survey. Based on this production rate, the individual gas constituents were calculated from the published data. The carbon dioxide emission comes due to the combustion of the gas in the internal combustion engine. Methane emission results due to leakage from the digester, as well as during the disposal of the waste from the digester. Sulphur dioxide, nitrous oxide and ammonia are possible harmful emissions from this method.

Composting is an aerobic digestion process in which the prime greenhouse gases (GHG) are $\mathrm{CO} 2, \mathrm{CH} 4$ and $\mathrm{N} 2 \mathrm{O}$ [33]. These are premier GHGs which can entrap heat and cause global warming, leading to climate change. During composting, the emissions are directly discharged into the atmosphere. Emission of methane thus causes much more damage as a greenhouse gas compared to carbon dioxide.

\subsection{Cost of the Fuel}

Municipal waste is available with an incentive, which means that households and other waste producers are ready to pay for its disposal. The major part of the fuel cost is due to handling and transportation. According to the World Bank classification of countries as per income levels and the corresponding municipal waste cost data, India, which is among the lower middle income countries, uses 30-75 USD for collection per ton of municipal solid waste. This includes pick up, transfer, transport to final disposal site and preparation of the fuel, in order to meet the requirements of the disposal technique. The total annual cost $\left(\mathrm{F}_{\mathrm{t}}\right)$ of waste can be the summation of the following costs minus the annual incentive cost $\left(C_{\text {in }}\right)$ stated above, namely,

- $\quad$ Labor wages (including the wages of the street cleaning groups), $\mathrm{C}_{\mathrm{cw}}$

- Operation and maintenance cost of waste collecting trucks (including fuel cost), $\mathrm{C}_{\mathrm{op}}$

- Wages of the collecting and transporting vehicles drivers and laborers, $\mathrm{C}_{\mathrm{tr}}$ 
- $\quad$ Administrative cost, $\mathrm{C}_{\mathrm{ad}}$

$$
\mathrm{F}_{\mathrm{t}}=\mathrm{C}_{\mathrm{cw}}+\mathrm{C}_{\mathrm{op}}+\mathrm{C}_{\mathrm{tr}}+\mathrm{C}_{\mathrm{ad}}-\mathrm{C}_{\mathrm{in}}
$$

The above costs can vary depending on the nature of the city, such as geographical area, distance of the waste dumping site, intermediate transfer stations if any, and climatic conditions prevailing in the area, like winter, summer or rain. Moreover, availability of infrastructural facility like roads and communication systems play an important role. Cost of labor is also related to the level of the city, like rural, semi urban and urban. Industrial development in the locality will be an indirect external factor influencing the cost of labor.

\subsection{Investment Cost}

Investment in land, plant and machinery and other infrastructural facility are technology specific. A considerable part of the cost of waste to energy projects is needed for prevention of damage to the environment. The cost incurred from the initial feasibility studies to the final commissioning of the plant usually involving several years depends on the project size and technology availability, and are subjected to subsidies from governmental agencies. These subsidies vary according to the prevailing economic and political conditions prevailing in the location.

Incineration technology can reduce the waste combustibles by 80 to 85 percent and can act as a substitute for conventional fossil fuel for energy generation. The plant involves pre-treatment system, the combustion system, the energy recovery system and the flue gas cleaning system. The cost of emission control systems depends on the pollution requirements of the area of installation. Rand et al. [34] gives the total cost of incineration plant (civil cost plus machinery cost), for an operating time of $7500 \mathrm{~h}$ per year. Linear fitting of the data given in this report gives the total cost (in million USD) equal to 0.34 times the plant capacity (in thousand metric tons).

Anaerobic digestion systems can either be a wet process if the dry matter content in the waste is less than $10 \%$, or dry process if the dry matter content is more than $20 \%$ [35]. They could also be continuous or batch type, depending on the waste generation capacity and consistency of waste quality for anaerobic digestion. The digester is the main functional component, followed by the gas processing system. The gas may be directly fired in an engine to replace diesel partially or fully in an engine. Alternatively, the gas may be used for heat generation in a boiler or process heating requirements. Waste gas treatment plant is also an essential part of these systems. Batch type and dry anaerobic digesters are robust installations with minimum maintenance costs, as explained by Kong et al. [36]. Anaerobic digestion systems compose of the following sections, namely, the mechanical treatment facility, biological treatment facility, mechanical composting facility and the residue acceptance area. The above source estimates the average cost of a new digester to be 561 USD per ton of waste. This cost data were obtained for a government project in California. A University of Columbia study found the cost for European projects to be similar.

Composting of municipal waste involves dumping the waste and maintaining the appropriate conditions of moisture content and temperature. Windrow composting is a simple process, in which the waste is dumped in the form of windrows and turned periodically and watered to maintain the required conditions. Investment cost depends on

- $\quad$ Size of the waste conversion facility

- Required ground cover or flooring for the windrows

- Facilities for preventing ground water contamination and storm water management

- Machinery for treatment and handling the waste

About $25 \mathrm{~m}^{2}$ of area is required for composting 1 ton of MSW, and it takes 21 to 30 days' time [37]. The cost in dollars $C=500+7.5 \times Q$, where $Q$ is the capacity in 1000 tons per year. 


\subsection{Operation and Maintenance Cost of the Disposal Process}

Operation of a waste disposal facility involves activities starting from waste procurement from the collection agency, to the final disposal of the residues and recoverable in an environmentally clean manner. The size of the disposal facility, the type of technology applied, and the level of automation involved affect the operation cost. According to the paper below, the methodology of waste treatment determines the operating cost of the waste incineration facility.

Operating and maintenance costs include, but are not restricted to the following items in a waste incineration facility.

- The electricity charges for equipment

- Cost of auxiliary fuel for combustion support

- Gas cleaning systems and other solid/liquid waste treatment systems

- Emission fee if applicable

- Labor cost

- Compensation costs for the local community

A detailed study of the operating and maintenance cost required for a waste to energy incineration plant of a capacity of 100,000 tons per year, and has suggested the average maintenance cost as $3 \%$ of the investment cost every year [38].

The costs for AD are likely to vary in accordance with the following factors [39]:

- Costs for acquisition of land

- The choice of technology to be used

- The nature of the waste used

- Efficiency of energy recovery

- Regulations concerning the conditions for utilization of by products and their treatment

Rapport et al. [40] gives the estimated operating and maintenance cost of anaerobic digesters in Europe to be USD 10.11 per ton of waste.

Composting involves the following operation and maintenance activities:

- Labor and machinery maintenance cost for tilling the waste, moisturizing and periodic inspection,

- Maintenance of the composting area, to prevent damage to the surrounding environment.

An average of eight locations for which operating and maintenance cost data were collected in a survey as reported in the following literature gives a value of USD 31.1 per ton of waste [37].

\subsection{End Product Cost}

This comprises the revenue obtained by sale of electricity, gas or compost from the waste disposal facility. Electricity is sold to the local community or supplied to the national grid, with financial incentives from the government agencies or the electricity companies. A wide variety of schemes have been introduced in different countries in order to support waste to electricity projects during the gestation periods, as well as during the lifetime of the project. A survey of six different waste to energy plants gives the average thermal energy produced as 2.7 MWhr per ton of waste [41]. These plants use different ratios of municipal wastes, mixed with other types of combustible wastes. Conversion of this thermal energy to electricity at 50\% efficiency gives an electricity output of $1.35 \mathrm{MWhr}$ per ton of waste. This makes the cost @ 0.02 US dollar (Indian price) as 108 USD per ton of waste. The central electricity commission of the government of India proposed the cost electricity produced from MSW at $0.101 \mathrm{USD} / \mathrm{KWhr}$ [42].

Estimated gas produced by anaerobic digesters is about 33 Watt per ton of waste. With gasification technology, one ton of MSW can be used to produce up to 1000 kilowatt-hours of electricity, a much more efficient and cleaner way to utilize this source of energy. This results in a revenue generation 
of USD 55.5 from one ton of MSW through the incineration route and USD 101 from one ton of MSW through anaerobic digestion route. On average, conventional waste-to-energy plants that use mass-burn incineration can convert one ton of MSW to about 550 kilowatt-hours of electricity. With gasification technology, one ton of MSW can be used to produce up to 1000 kilowatt-hours of electricity, a much more efficient and cleaner way to utilize this source of energy [26]. This results in a revenue generation of USD 55.5 from one ton of MSW through the incineration route and USD 101 from one ton of MSW through anaerobic digestion route. Composting produces 400-600 kg of compost from 1 ton of waste as arrived, which contains $50-60 \%$ of organic matter. Compost costs about USD 50 per ton [37].

\subsection{Raw Material Supply Condition}

The waste generation and collection rate differ with seasons and due to other reasons. In the case of batch type incinerators this may not have much impact, but it definitely creates operational difficulties in continuous type incinerators, especially if there is no adequate inventory. Continuous incineration requires continuous uninterrupted supply for efficient operation. Similarly, gasifiers also are either batch type of continuous types. However, since volumetric feed flow is much lesser in gasification systems, continuity of feed flow or its moisture content is not a major issue. Composting is least affected by continuity of MSW supply.

\subsection{Public Perception}

Among incineration, anaerobic digestion and composting, incineration has the lowest rank in public perception, due to the possible environmental damage effects from this technology, and composting has the highest rank in terms of acceptance by the public. Composting is rarely acceptable in semi urban communities, due to better end use prospects compared to developed communities.

Thus, three waste management strategies, in accordance with the above stated relevant waste disposal regulations, are examined and tested for three different scenarios namely Type 1 cities, Type 2 cities and Type 3 cities; and are presented in the following Tables 4-6 respectively.

\section{Adopted Approach: Application}

After standardization of all evaluation criteria (refer to Equations from (1) to (3)), the decision matrix is expressed for each city type as here below in Table 6. Using standardization of all evaluation criteria (refer to Table 7), $\mathrm{E}_{\mathrm{j}}$ an entropy weight of the jth criterion is determined by Equation (4). Obtained $E_{j}$ values are presented here below in Table 8.

Table 7. Standardized Decision matrix $S_{i j}^{\prime}$ for three cities for three types of treatment strategies.

\begin{tabular}{cccccccccc}
\hline Three Cities $\rightarrow$ & \multicolumn{3}{c}{ Type 1 Cities } & \multicolumn{3}{c}{ Type 2 Cities } & \multicolumn{3}{c}{ Type 3 Cities } \\
\hline \multirow{2}{*}{$\begin{array}{c}\text { Evaluation } \\
\text { Criterion } \mathbf{j}\end{array}$} & \multicolumn{2}{c}{ \# Alternative Waste } & \multicolumn{2}{c}{$\begin{array}{c}\text { Alternative Waste } \\
\text { Treatment Strategies }\end{array}$} & \multicolumn{2}{c}{$\begin{array}{c}\text { Alternative Waste } \\
\text { Treatment Strategies }\end{array}$} & \multicolumn{2}{c}{ Treatmegies } \\
\cline { 2 - 10 } & $\mathbf{i}=\mathbf{1}$ & $\mathbf{i}=\mathbf{2}$ & $\mathbf{i}=\mathbf{3}$ & $\mathbf{i}=\mathbf{1}$ & $\mathbf{i}=\mathbf{2}$ & $\mathbf{i}=\mathbf{3}$ & $\mathbf{i}=\mathbf{1}$ & $\mathbf{i}=\mathbf{2}$ & $\mathbf{i}=\mathbf{3}$ \\
\hline 1 & 0 & 1 & 0.714 & 0 & 1 & 0.715 & 0 & 1 & 0.744 \\
2 & 0 & 1 & 1 & 0 & 1 & 1 & 0 & 1 & 1 \\
3 & 0.759 & 1 & 0 & 1 & 0 & 1 & 0.759 & 1 & 0 \\
4 & 0.965 & 1 & 0 & 0.965 & 1 & 0 & 0.965 & 1 & 0 \\
5 & 1 & 0.787 & 0 & 1 & 0.787 & 0 & 1 & 0.796 & 0 \\
6 & 0 & 0.999 & 1 & 0 & 0.999 & 1 & 0 & 0.999 & 1 \\
7 & 1 & 0 & 0.956 & 1 & 0 & 0.956 & 0.940 & 1 & 0 \\
8 & 0 & 0.999 & 1 & 0 & 0.999 & 1 & 0 & 0.999 & 1 \\
9 & 0 & 1 & 1 & 0 & 1 & 1 & 0 & 1 & 1 \\
10 & 0 & 1 & 1 & 0 & 1 & 1 & 0 & 1 & 1 \\
11 & 0.983 & 1 & 0 & 0.983 & 1 & 0 & 0.983 & 1 & 0 \\
12 & 0 & 0.999 & 1 & 0 & 0.999 & 1 & 0 & 0.999 & 1 \\
13 & 0 & 0.999 & 1 & 0 & 0.999 & 1 & 0 & 0.999 & 1 \\
\hline
\end{tabular}


Table 7. Cont.

\begin{tabular}{cccccccccc}
\hline Three Cities $\rightarrow$ & \multicolumn{2}{c}{ Type 1 Cities } & \multicolumn{2}{c}{ Type 2 Cities } & \multicolumn{3}{c}{ Type 3 Cities } \\
\hline \multirow{2}{*}{$\begin{array}{c}\text { Evaluation } \\
\text { Criterion } \mathbf{j}\end{array}$} & \multicolumn{2}{c}{ \# Alternative Waste } & \multicolumn{2}{c}{$\begin{array}{c}\text { Alternative Waste } \\
\text { Treatment Strategies }\end{array}$} & \multicolumn{2}{c}{$\begin{array}{c}\text { Alternative Waste } \\
\text { Treatment Strategies }\end{array}$} \\
\cline { 2 - 10 } & $\mathbf{i}=\mathbf{1}$ & $\mathbf{i}=\mathbf{2}$ & $\mathbf{i}=\mathbf{3}$ & $\mathbf{i}=\mathbf{1}$ & $\mathbf{i}=\mathbf{2}$ & $\mathbf{i}=\mathbf{3}$ & $\mathbf{i}=\mathbf{1}$ & $\mathbf{i}=\mathbf{2}$ & $\mathbf{i}=\mathbf{3}$ \\
\hline 14 & 0 & 0.999 & 1 & 0 & 0.999 & 1 & 0 & 0.999 & 1 \\
15 & 1 & 0 & 0.312 & 1 & 0 & 0.312 & 1 & 0.991 & 0 \\
16 & 0 & 0.123 & 1 & 0 & 0.123 & 1 & 0 & 0.123 & 1 \\
17 & 0 & 1 & 0.999 & 0 & 1 & 0.999 & 0 & 1 & 0.999 \\
18 & 0 & 0.120 & 1 & 0 & 0.120 & 1 & 0 & 0.120 & 1 \\
19 & 1 & 1 & 0 & 0 & 1 & 1 & 1 & 0.5 & 0 \\
20 & 1 & 1 & 0 & 0 & 1 & 1 & 1 & 1 & 0 \\
21 & 1 & 1 & 0 & 0 & 1 & 1 & 1 & 1 & 0 \\
22 & 1 & 1 & 0 & 1 & 0 & 1 & 1 & 1 & 0 \\
\hline
\end{tabular}

Table 8. Entropy Weights $\left(E_{j}\right)$ values for each evaluation criterion.

\begin{tabular}{ccccc}
\hline${ }^{*}$ Evaluation Criterion (j) & Type 1 Cities $\mathbf{E}_{\mathbf{j}}$ & Type 2 Cities $\mathbf{E}_{\mathbf{j}}$ & ${\text { Type 3 Cities } \mathbf{E}_{\mathbf{j}}}$ & Average $\mathbf{j}$ \\
\hline 1 & 0.0429 & 0.0428 & 0.0432 & 0.0430 \\
2 & 0.0466 & 0.0464 & 0.0465 & 0.0465 \\
3 & 0.0434 & 0.0464 & 0.0434 & 0.0444 \\
4 & 0.0460 & 0.0459 & 0.0460 & 0.0460 \\
5 & 0.0437 & 0.0436 & 0.0438 & 0.0437 \\
6 & 0.0466 & 0.0464 & 0.0465 & 0.0465 \\
7 & 0.0459 & 0.0458 & 0.0457 & 0.0458 \\
8 & 0.0466 & 0.0464 & 0.0465 & 0.0465 \\
9 & 0.0466 & 0.0464 & 0.0465 & 0.0465 \\
10 & 0.0466 & 0.0464 & 0.0465 & 0.0465 \\
11 & 0.0463 & 0.0462 & 0.0463 & 0.0462 \\
12 & 0.0466 & 0.0464 & 0.0465 & 0.0465 \\
13 & 0.0466 & 0.0464 & 0.0465 & 0.0465 \\
14 & 0.0466 & 0.0464 & 0.0465 & 0.0465 \\
15 & 0.0411 & 0.0410 & 0.0464 & 0.0428 \\
16 & 0.0427 & 0.0425 & 0.0427 & 0.0426 \\
17 & 0.0466 & 0.0464 & 0.0465 & 0.0465 \\
18 & 0.0427 & 0.0426 & 0.0427 & 0.0427 \\
19 & 0.0466 & 0.0464 & 0.0413 & 0.0448 \\
20 & 0.0466 & 0.0464 & 0.0465 & 0.0465 \\
21 & 0.0466 & 0.0464 & 0.0465 & 0.0465 \\
22 & 0.0466 & 0.0464 & 0.0465 & 0.0465 \\
\hline
\end{tabular}

Note: * refer Table 2.

The decision matrix of three waste treatment strategies decision-making and 22 evaluation criterions are established according to the data in the Table 7 . The normalized decision matrix is established, and weighted decision matrix is estimated using (7), and the best solution and the worst solution values are obtained by using Equations (8) and (9). They are shown as follows in Table 9. The distance of each waste treatment strategy from the overall best alternative treatment strategy and the overall worst alternative treatment strategy is obtained according to Equations (10) and (11). Finally, three waste treatment strategies are ranked (refer Table 10) by the relative degree of approximation using Equation (12). 
Table 9. Best and worst solution for each criterion.

\begin{tabular}{cccccc}
\hline${ }^{*}$ Evaluation Criterion $\mathbf{( j )}$ & $\mathbf{\mathbf { V } _ { \mathbf { 1 j } }}$ & $\mathbf{V}_{\mathbf{2} \mathbf{j}}$ & $\mathbf{V}_{\mathbf{3 j}}$ & $\mathbf{V}^{+}$ & $\mathbf{V}^{-}$ \\
\hline 1 & 0.038807 & 0.008133 & 0.01662 & 0.008133 & 0.038806994 \\
2 & 0.004663 & 0 & 0 & 0 & 0.004662782 \\
3 & 0.005482 & $2.59 \times 10^{-5}$ & 0.022807 & $2.59 \times 10^{-5}$ & 0.022806629 \\
4 & $8.26 \times 10^{-7}$ & $5.23 \times 10^{-5}$ & 0.000918 & $5.23 \times 10^{-5}$ & 0.000918323 \\
5 & 0.000148 & 0.001748 & 0.007869 & 0.000148 & 0.007868578 \\
6 & 0.003 & $5.66 \times 10^{-9}$ & 0 & 0 & 0.00299954 \\
7 & 0.001637 & 0.010258 & 0.009404 & 0.001637 & 0.010257574 \\
8 & 0.000279 & $1.95 \times 10^{-9}$ & 0 & 0 & 0.000278595 \\
9 & 0.001662 & 0 & 0 & 0 & 0.001662285 \\
10 & 0.008571 & 0 & 0 & 0 & 0.008571456 \\
11 & 0.000157 & 0 & 0.009254 & 0 & 0.009254442 \\
12 & 0.000474 & $2.8 \times 10^{-11}$ & 0 & 0 & 0.000473612 \\
13 & 0.000715 & $1.13 \times 10^{-7}$ & 0 & 0 & 0.000715023 \\
14 & 0.009556 & $1.39 \times 10^{-10}$ & 0 & 0 & 0.009555815 \\
15 & 0 & 0.058144 & 0.054571 & 0 & 0.058144095 \\
16 & 0.036373 & 0.031875 & $2.75 \times 10^{-7}$ & $2.75 \times 10^{-7}$ & 0.036373418 \\
17 & 0.000697 & $1.35 \times 10^{-7}$ & $3.98 \times 10^{-7}$ & $1.35 \times 10^{-7}$ & 0.000696669 \\
18 & 0.00017 & 0.000219 & 0.000146 & 0.000146 & 0.00021908 \\
19 & 0.000179 & 0.00023 & 0.000153 & 0.000153 & 0.000229864 \\
20 & 0.000239 & 0.000212 & 0.000159 & 0.000239 & 0.000159197 \\
21 & 0.008597 & 0.008039 & 0.00398 & 0.008597 & 0.003979931 \\
22 & 0.000212 & 0.000212 & 0.000133 & 0.000212 & 0.000132664 \\
\hline
\end{tabular}

Note: * refer Table $2 ; \mathrm{V}_{1 \mathrm{j}}$ : best weighted normalized value for criterion $\mathrm{j}$ for alternative waste treatment strategy $\mathrm{i}=1$; $V_{2 j}$ : best weighted normalized value for criterion $j$ for alternative waste treatment strategy $i=2 ; V_{3 j}$ : best weighted normalized value for criterion $j$ for alternative waste treatment strategy $i=3 ; V^{+}$: best weighted normalized value for criterion $\mathrm{j}$; and $\mathrm{V}^{-}$: worst weighted normalized value for criterion $\mathrm{j}$.

Table 10. Three waste treatment strategies and their ranks.

\begin{tabular}{ccccc}
\hline Treatment Strategy & $\mathbf{D}_{\mathbf{i}}{ }^{+}$ & $\mathbf{D}_{\mathbf{i}}{ }^{-}$ & $\mathbf{D}_{\mathbf{i}}{ }^{-} /\left(\mathbf{D}_{\mathbf{i}}{ }^{+}+\mathbf{D}_{\mathbf{i}}{ }^{-}\right)$ & $\mathbf{C}_{\mathbf{i}}$ \\
\hline Incineration (i=1) & 0.049932595 & 0.062606622 & 0.556309381 & Rank 1 \\
Anaerobic Digestion (i = 2) & 0.066887651 & 0.04266154 & 0.389428159 & Rank 3 \\
Composting (i = 3) & 0.061616589 & 0.045037421 & 0.422275926 & Rank 2 \\
\hline
\end{tabular}

Note: $\mathrm{D}_{\mathrm{i}}{ }^{+}$an alternative waste treatment strategy distance from the best ideal alternative; $\mathrm{D}_{\mathrm{i}}{ }^{-}$: an alternative waste treatment strategy distance from the worst ideal alternative; and $C_{i}$ : an alternative waste treatment strategy closeness from the other alternatives.

\section{Results and Discussion}

The best and worst solutions for each of the criterion are shown in Table 9. The distance of each waste treatment strategy from the overall best alternative treatment strategy and the overall worst alternative treatment strategy is obtained according to Equations (10) and (11). Finally, three waste treatment strategies are ranked (refer Table 10) by the relative degree of approximation using Equation (12).

It is evident that incineration strategy is best preference to minimize $\mathrm{N}_{2} \mathrm{O}$ and $\mathrm{NH}_{3}$ index; whereas anaerobic digestion is best preferred to minimize $\mathrm{CO}_{2}$ and $\mathrm{SO}_{2}$ index, and composting is opted to minimize $\mathrm{CO}, \mathrm{HCL}$ and HF. Similarly, by adopting anaerobic digestion one can minimize particulate matters, dioxins, and poly-aromatic hydrocarbons in the environment; whereas composting treatment strategy helps to minimize cadmium, mercury and other heavy metals. Overall public perception is best towards incineration treatment strategy and worst towards composting. This is in agreement with the current perception because the increased contamination levels in the underground water sources. These waste treatment strategies not only have their own characteristics and feasibility, but also defer on their preference for each criterion. Thus, distance of each waste treatment strategy from the overall best alternative treatment strategy and the overall worst alternative treatment strategy is obtained and three waste treatment strategies are ranked (refer Table 10) by the relative degree of approximation. 
It is observed that experts are having diverse preference weights for the evaluation criterion, and it varies city to city. For example, although maximum concern goes for minimization of carbon monoxide to achieve green sustainable environment, particulate matter and dioxin level are second and third most concern, for Type 1 cities and Type 3 cities respectively. Meeting minimum supply rate of waste and meeting fuel quality requirements are among top five criterion to run the process plant. Considering the need of global requirement to dispose-off various waste material, without harming ecosystem, the experts are of view that initial investment cost should be give least weightage. It is also important that while selecting the treatment strategy one has to focus on public perception in top five concerns, to avoid any social conflicts. Thus, decision maker needs to select the most suitable waste treatment strategy, in order to achieve the desired global energy output with minimum cost and specific application ability. As can be seen from Table 10, evaluation ranks of three waste treatment strategies are as follows: Incineration > Composting > Anaerobic Digestion. The results obtained by this method are reasonable. The entropy weight and TOPSIS method, which have high resolution and simple calculation process, could objectively evaluate waste treatment strategies. This approach is different as compared to the other known approaches. Here, the approach incorporates the fuzzy nature of decision-making. It synthesizes the preference relationships for each alternative, to produce the desired outranking relationship between the entire alternative waste treatment strategies. A sensitivity analysis can also be performed to see the effect of the variation in the importance that is assigned to objective criteria.

\section{Conclusions}

Selection of waste treatment strategy for a specific city is one of the most challenging problems in the real waste management environment. A multi criterion evaluation system using TOPSIS was done to evaluate the suitable waste to energy conversion system for three different levels of community, by considering the five different and prominent factors, namely, environmental concerns, cost concerns, end product cost, ability to tolerate raw material supply variation and public perception. Three types of communities, namely, European city (Type 1 cities), ' $A$ ' grade Indian city (Type 2 cities) and 'B' grade Indian city (Type 3 cities) were considered for this study. The waste conversion technology applied for this analysis includes incineration, anaerobic digestion and composting. Different measurable factors were used in the analysis for municipal solid waste treatment strategies. From among various alternatives, three prominent strategies, namely, incineration, anaerobic digestion and composting are considered for the evaluation. Exhaustive data collection is done from conducting field studies as well as from published data. A comparative study to find the effectiveness of the TOPSIS method was done, and it was demonstrated the TOPSIS results are reliable and are more coincident with the reality. Results of this method can identify the individual preferable method of waste conversion, based on their respective performance in terms of pollutant production. Results of the study indicate that the rankings were similar for all the three types of communities, and in the order incineration, composting and anaerobic digestion. Incineration was most preferred due to the option of end use energy production, which made the process attractive. Anaerobic digestion involved high investment and maintenance requirements, making it the least attractive option. These results can be used for policy makers to choose the appropriate technology in the above types of communities and help to achieve the unified goal of sustainable development.

Author Contributions: Conceptualization, Z.K. and A.U.R.; methodology, A.U.R. and Y.S.U.; formal analysis, Z.K., A.U.R., Y.S.U. and U.U.; investigation Z.K., A.U.R. and Y.S.U.; resources, A.U.R. and U.U.; writing-Original draft preparation, Z.K. and A.U.R.; writing-Review and editing, A.U.R., Y.S.U. and U.U.; supervision, Z.K. and A.U.R.; funding acquisition, A.U.R. All authors have read and agreed to the published version of the manuscript.

Funding: Deanship of Scientific Research at King Saud University grant number-RG-1439-005.

Acknowledgments: The authors extend their appreciation to the Deanship of Scientific Research at King Saud University for funding this work through research group number RG-1439-005.

Conflicts of Interest: The authors declare no conflict of interest. 


\section{References}

1. Tourangeau, R.; Maitland, A.; Steiger, D.; Yan, T. A Framework for Making Decisions about Question Evaluation Methods. In Advances in Questionnaire Design, Development, Evaluation and Testing; John Wiley \& Sons, Ltd.: Hoboken, NJ, USA, 2019; pp. 47-73, ISBN 978-1-119-26368-5.

2. Behzadian, M.; Khanmohammadi Otaghsara, S.; Yazdani, M.; Ignatius, J. A state-of the-art survey of TOPSIS applications. Expert Syst. Appl. 2012, 39, 13051-13069. [CrossRef]

3. Ding, L.; Shao, Z.; Zhang, H.; Xu, C.; Wu, D. A Comprehensive Evaluation of Urban Sustainable Development in China Based on the TOPSIS-Entropy Method. Sustainability 2016, 8, 746. [CrossRef]

4. Solangi, Y.A.; Tan, Q.; Mirjat, N.H.; Ali, S. Evaluating the strategies for sustainable energy planning in Pakistan: An integrated SWOT-AHP and Fuzzy-TOPSIS approach. J. Clean. Prod. 2019, 236, 117655. [CrossRef]

5. Memari, A.; Dargi, A.; Akbari Jokar, M.R.; Ahmad, R.; Rahim, A.R.A. Sustainable supplier selection: A multi-criteria intuitionistic fuzzy TOPSIS method. J. Manuf. Syst. 2019, 50, 9-24. [CrossRef]

6. Ukoba, M.O.; Diemuodeke, O.E.; Alghassab, M.; Njoku, H.I.; Imran, M.; Khan, Z.A. Composite Multi-Criteria Decision Analysis for Optimization of Hybrid Renewable Energy Systems for Geopolitical Zones in Nigeria. Sustainability 2020, 12, 5732. [CrossRef]

7. Saeli, M.; Micale, R.; Seabra, M.P.; Labrincha, J.A.; La Scalia, G. Selection of Novel Geopolymeric Mortars for Sustainable Construction Applications Using Fuzzy Topsis Approach. Sustainability 2020, $12,5987$. [CrossRef]

8. Sambasivam, V.P.; Thiyagarajan, G.; Kabir, G.; Ali, S.M.; Khan, S.A.R.; Yu, Z. Selection of Winter Season Crop Pattern for Environmental-Friendly Agricultural Practices in India. Sustainability 2020, 12, 4562. [CrossRef]

9. Bandara, N.J.G.J.; Hettiaratchi, J.P.A.; Wirasinghe, S.C.; Pilapiiya, S. Relation of waste generation and composition to socio-economic factors: A case study. Environ. Monit. Assess. 2007, 135, 31-39. [CrossRef]

10. Mazzanti, M.; Zoboli, R. Waste generation, waste disposal and policy effectiveness: Evidence on decoupling from the European Union. Resour. Conserv. Recycl. 2008, 52, 1221-1234. [CrossRef]

11. Zhang, D.; Keat, T.S.; Gersberg, R.M. A comparison of municipal solid waste management in Berlin and Singapore. Waste Manag. 2010, 30, 921-933. [CrossRef]

12. Murer, M.J.; Spliethoff, H.; De Waal, C.M.W.; Wilpshaar, S.; Berkhout, B.; Van Berlo, M.A.J.; Gohlke, O.; Martin, J.J.E. High efficient waste-to-energy in Amsterdam: Getting ready for the next steps. Waste Manag. Res. 2011, 29, S20-S29. [CrossRef] [PubMed]

13. Talyan, V.; Dahiya, R.P.; Sreekrishnan, T.R. State of municipal solid waste management in Delhi, the capital of India. Waste Manag. 2008, 28, 1276-1287. [CrossRef] [PubMed]

14. Yedla, S.; Kansal, S. Economic insight into municipal solid waste management in Mumbai: A critical analysis. Int. J. Environ. Pollut. 2003, 19, 516-527. [CrossRef]

15. Das, S.; Bhattacharyya, B.K. Estimation of Municipal Solid Waste Generation and Future Trends in Greater Metropolitan Regions of Kolkata, India. J. Ind. Eng. Manag. Innov. 2014, 1, 31-38. [CrossRef]

16. Sujatha, P.; Janardhanam, P.V.S. Solid Waste Management in Chennai City; South Eastern University of Sri Lanka: Oluvil, Sri Lanka, 2011; ISBN 978-955-627-002-0.

17. Katpatal, Y.B.; Rama Rao, B.V.S. Urban Spatial Decision Support System for Municipal Solid Waste Management of Nagpur Urban Area Using High-Resolution Satellite Data and Geographic Information System. J. Urban Plan. Dev. 2011, 137, 65-76. [CrossRef]

18. Yadav, V.; Karmakar, S.; Dikshit, A.K.; Vanjari, S. A feasibility study for the locations of waste transfer stations in urban centers: A case study on the city of Nashik, India. J. Clean. Prod. 2016, 126, 191-205. [CrossRef]

19. Chandramohan, A.; Ravichandran, C.; Sivasankar, V. Solid waste, its health impairments and role of rag pickers in Tiruchirappalli city, Tamil Nadu, Southern India. Waste Manag. Res. 2010, 28, 951-958. [CrossRef]

20. Samadder, S.R.; Prabhakar, R.; Khan, D.; Kishan, D.; Chauhan, M.S. Analysis of the contaminants released from municipal solid waste landfill site: A case study. Sci. Total Environ. 2017, 580, 593-601. [CrossRef]

21. Mihai, F.; Apostol, L. Disparities in Municipal Waste Management across EU-27. A Geographical Approach; Social Science Research Network: Rochester, NY, USA, 2012.

22. Kumar, S.; Smith, S.R.; Fowler, G.; Velis, C.; Arya, S.; Rena; Kumar, R.; Cheeseman, C.; Kumar, S.J. Challenges and opportunities associated with waste management in India. R. Soc. Open Sci. 2017, 4, 160764. [CrossRef] 
23. Dutta, A.; Jinsart, W. Waste generation and management status in the fast-expanding Indian cities: A review. J. Air Waste Manag. Assoc. 2020, 70, 491-503. [CrossRef]

24. Sabbas, T.; Polettini, A.; Pomi, R.; Astrup, T.; Hjelmar, O.; Mostbauer, P.; Cappai, G.; Magel, G.; Salhofer, S.; Speiser, C.; et al. Management of municipal solid waste incineration residues. Waste Manag. 2003, 23, 61-88. [CrossRef]

25. Mutz, D.; Hengevoss, D.; Hugi, C.; Gross, T. Waste-to-Energy Options in Municipal Solid Waste Management A Guide for Decision Makers in Developing and Emerging Countries. Available online: https://www.giz.de/ en/downloads/GIZ_WasteToEnergy_Guidelines_2017.pdf (accessed on 1 December 2019).

26. Renkow, M.; Rubin, A.R. Does municipal solid waste composting make economic sense? J. Environ. Manag. 1998, 53, 339-347. [CrossRef]

27. Rehman, A.U.; Alkhatani, M.; Umer, U. Multi Criteria Approach to Measure Leanness of a Manufacturing Organization. IEEE Access 2018, 6, 20987-20994. [CrossRef]

28. Wang, T.-C.; Chang, T.-H. Application of TOPSIS in evaluating initial training aircraft under a fuzzy environment. Expert Syst. Appl. 2007, 33, 870-880. [CrossRef]

29. Jeswani, H.K.; Azapagic, A. Assessing the environmental sustainability of energy recovery from municipal solid waste in the UK. Waste Manag. 2016, 50, 346-363. [CrossRef]

30. Jarnicka, J.; Żebrowski, P. Learning in greenhouse gas emission inventories in terms of uncertainty improvement over time. Mitig. Adapt. Strat. Glob. Chang. 2019, 24, 1143-1168. [CrossRef]

31. Chan, Y.C.; Sinha, R.K.; Wang, W. Emission of greenhouse gases from home aerobic composting, anaerobic digestion and vermicomposting of household wastes in Brisbane (Australia). Waste Manag. Res. 2011, 29, 540-548. [CrossRef]

32. Das, S.; Lee, S.-H.; Kumar, P.; Kim, K.-H.; Lee, S.S.; Bhattacharya, S.S. Solid waste management: Scope and the challenge of sustainability. J. Clean. Prod. 2019, 228, 658-678. [CrossRef]

33. Sánchez, A.; Artola, A.; Font, X.; Gea, T.; Barrena, R.; Gabriel, D.; Sánchez-Monedero, M.Á.; Roig, A.; Cayuela, M.L.; Mondini, C. Greenhouse Gas from Organic Waste Composting: Emissions and Measurement. In $\mathrm{CO}_{2}$ Sequestration, Biofuels and Depollution; Lichtfouse, E., Schwarzbauer, J., Robert, D., Eds.; Environmental Chemistry for a Sustainable World; Springer International Publishing: Cham, Germany, 2015; pp. 33-70, ISBN 978-3-319-11906-9.

34. Rand, T.; Haukohl, J.; Marxen, U. Municipal Solid Waste Incineration: Requirements for a Successful Project; World Bank Publications: Washington, DC, USA, 2000; ISBN 978-0-8213-4668-6.

35. Scarlat, N.; Fahl, F.; Dallemand, J.-F. Status and Opportunities for Energy Recovery from Municipal Solid Waste in Europe. Waste Biomass Valor. 2019, 10, 2425-2444. [CrossRef]

36. Kong, Z.; Li, L.; Xue, Y.; Yang, M.; Li, Y.-Y. Challenges and prospects for the anaerobic treatment of chemical-industrial organic wastewater: A review. J. Clean. Prod. 2019, 231, 913-927. [CrossRef]

37. Abad, V.; Avila, R.; Vicent, T.; Font, X. Promoting circular economy in the surroundings of an organic fraction of municipal solid waste anaerobic digestion treatment plant: Biogas production impact and economic factors. Bioresour. Technol. 2019, 283, 10-17. [CrossRef] [PubMed]

38. Cucchiella, F.; D'Adamo, I.; Gastaldi, M. Sustainable waste management: Waste to energy plant as an alternative to landfill. Energy Convers. Manag. 2017, 131, 18-31. [CrossRef]

39. Hilkiah Igoni, A.; Ayotamuno, M.J.; Eze, C.L.; Ogaji, S.O.T.; Probert, S.D. Designs of anaerobic digesters for producing biogas from municipal solid-waste. Appl. Energy 2008, 85, 430-438. [CrossRef]

40. Rapport, J.L.; Zhang, R.; Williams, R.B.; Jenkins, B.M. Anaerobic Digestion technologies for the treatment of Municipal Solid Waste. Int. J. Environ. Waste Manag. 2011, 9, 100-122. [CrossRef]

41. Kalogirou, E.N. Waste-to-Energy Technologies and Global Applications; CRC Press: Boca Raton, FL, USA, 2017; ISBN 978-1-351-97791-3.

42. Singh, M. Forecasting of waste-to-energy system: A case study of Faridabad, India. Energy Sources Part A Recovery Util. Environ. Eff. 2020, 42, 319-328. [CrossRef]

(C) 2020 by the authors. Licensee MDPI, Basel, Switzerland. This article is an open access article distributed under the terms and conditions of the Creative Commons Attribution (CC BY) license (http://creativecommons.org/licenses/by/4.0/). 